\title{
Better lives: social insight isn't enough
}

\section{Nicholas Maxwell}

Nature, 580, p. 456, 23 April 2020

Hetan Shah argues that global problems need social science to help solve them (Nature 577, 295 ; 2020). I contend that he is both right and profoundly wrong.

Developing social inquiry as social 'science' is a blunder that goes all the way back to the eighteenth-century Enlightenment (see go.nature.com/34exatc). To promote human welfare, academia needs to provide practical solutions to problems of suffering, poverty, injustice and avoidable death. It needs to articulate and assess possible solutions in terms of actions, policies, political programmes, philosophies of life and ways of living. The task of social inquiry and the humanities is to guide people on how to resolve such issues and conflicts in effective, intelligent, humane ways . In connection with the climate crisis, for example, the public needs to know precisely what needs to be done by governments, businesses, the media, public institutions and individuals to mitigate global warming.

However, social scientists down the decades have fallen short in providing such guidance. In my view, this is because their focus has been on acquiring knowledge about society when it should instead be on promoting social progress towards as good a world as possible.

doi: https://doi.org/10.1038/d41586-020-01146-6 


\section{Social insight must improve lives}

Hetan Shah argues that global problems need social science (Nature 577, 295; 2020). I contend that he is both right and profoundly wrong.

Developing social inquiry as social 'science' is a blunder that goes all the way back to the eighteenth-century Enlightenment (see go.nature. com/2wekz5p). To promote human welfare, academia needs to help solve the problems of suffering, poverty, injustice and avoidable death. It needs to articulate and assess possible solutions in terms of actions, policies, political programmes, philosophies of life and ways of living.

Guiding people on how to resolve such issues and conflicts in effective, intelligent, humane ways is the task of social inquiry and the humanities. In connection with the climate crisis, for example, the public needs to know precisely what needs to be done by governments, businesses, the media, public institutions and individuals to put a stop to global warming. However, social scientists down the decades have fallen short in providing such guidance. In my view, this is because their focus has been on acquiring knowledge about society when it should instead be on promoting social progress towards as good a world as possible.

Nicholas Maxwell University College London, UK. 
nicholas.maxwell@ucl.ac.uk

\section{Letter to the Editor of Nature}

Hetan Shah argues that "global problems need social science" (Nature, 15 January, 577, $295,2020)$. He is both right and profoundly wrong. In a body of work going back to 1976, I have shown decisively that developing social inquiry as social science is a monumental blunder that goes all the way back to the $18^{\text {th }}$ century Enlightenment. ${ }^{1}$ Granted that a basic aim of academia is to help promote human welfare, the problems that academia, fundamentally, needs to help solve are problems of living, problems of human suffering, poverty, injustice, avoidable death. The proper, fundamental intellectual task of academia is to (1) articulate problems of living, and (2) propose and critically assess possible solutions possible actions, policies, political programmes, philosophies of life, ways of living. A basic task must be to help people resolve conflicts and problems of living in increasingly effective, intelligent, humane ways. All this is the proper task of social inquiry and the humanities. In connection with the climate crisis, the task must be to make abundantly clear to the public precisely what needs to be done, what governments, businesses, the media, public institutions and individuals need to do, to put a stop to global warming.

Have social scientists acted in this way down the decades since we became aware of the menace of climate change in the early 1960s? No! Why not? Because they have profoundly misconceived their task. Instead of helping people work out what to do to solve problems of living, including global problems, they have sought merely to solve problems of knowledge about the social world. Instead of actively helping to promote social progress towards as good a world as possible, they have merely contributed to progress in knowledge about the social world.

\footnotetext{
${ }^{1}$ https://www.ucl.ac.uk/from-knowledge-to-wisdom/publications
} 